\title{
Targeting Voltage-Gated Calcium Channels for Neuropathic Pain Management
}

\author{
Danielle Perret** and Z. David Luo* ${ }^{* \dagger}$ \\ *Department of Anesthesiology \& Perioperative Care, ${ }^{\dagger}$ Department of Pharmacology, and Department of Physical Medicine \& \\ Rehabilitation, School of Medicine, University of California Irvine, Irvine, California 92697
}

\begin{abstract}
Summary: Voltage-gated calcium channels (VGCC) play obligatory roles in diverse physiological functions. Pathological conditions leading to changes in their biophysical properties and expression levels may cause malfunctions of VGCC-mediated activities, resulting in disease states. It is believed that changes in VGCC properties under pain-inducing conditions may play a causal role in the development of chronic pain, including nerve injury-induced pain or neuropathic pain. For the past several decades, preclinical and clinical research in developing VGCC blockers or modulators for chronic pain management has been fruitful, leading to some U.S. Food and Drug Administration-approved drugs currently available for chronic pain management. However, their efficacy in pain re-
\end{abstract}

lief is limited in some patients, and their long-term use is limited by their side-effect profiles. Certainly, there is room for improvement in developing more subtype-specific VGCC blockers or modulators for chronic pain conditions. In this review, we summarized the most recent preclinical and clinical studies related to chronic pain medications acting on the VGCC. We also included clinical trials aiming to expand the application of approved VGCC drugs to different pain states derived from various pathological conditions, as well as drug combination therapies trying to improve the efficacies and side-effect profiles of current pain medications. Key Words: Chronic, neuropathic pain, voltage-gated calcium channels, analgesics.

\section{INTRODUCTION}

A recent survey has indicated that at least 50 million people in the United States suffer from chronic pain. ${ }^{1}$ It is predicted that this number will increase dramatically due to advances in health care that will continue to prolong the lifespan of patients. In addition to adversely affecting quality of life, inadequate management of chronic pain also has profound social, economical, and psychological consequences. Current pain medications, both opioid and nonopioid, at best, cause partial pain relief in some, but not all, patients. In addition, long-term usage of these medications is often associated with intolerable side effects, some of which can be life-threatening. Therefore, there is an urgent need for safer and more specific analgesic medications for chronic pain management.

Even though different etiologies of chronic pain may have similar clinical manifestations, chronic pain can

Address correspondence and reprint requests to: Z. David Luo, M.D., Ph.D., Department of Anesthesiology \& Perioperative Care, University of California, Irvine Medical Center, Bldg 53, Room 227, 101 The City Dr. South, Orange, CA 92868. E-mail: zluo@uci.edu. derive from different pathological conditions that each mediate chronic pain states by unique mechanisms. Thus, directing our treatment toward a limited number of targets by medications in our current toolbox could render partial pain relief in some patients only. Combinational treatment is an option to improve efficacy and reduce side effects. Unfortunately, most of the currently available analgesic medications act through targets that are not only important in pain processing, but also critical in mediating normal physiological functions, which therefore lead to intolerable side effects, especially after long-term usage. Individualized pain management based on pain-inducing pathological conditions would have the least interference with normal physiological functions, and is therefore an ideal approach in chronic pain management.

Voltage-gated calcium channels (VGCC) or their subunits are considered one family of molecules with therapeutic potentials in chronic pain management. The VGCC are assembled through interactions of different subunits, ${ }^{2}$ namely $\alpha 1\left(\mathrm{Ca}_{\mathrm{V}} \alpha 1\right), \beta\left(\mathrm{Ca}_{\mathrm{V}} \beta\right) \alpha_{2} \delta\left(\mathrm{Ca}_{\mathrm{V}} \alpha_{2} \delta\right)$ and $\gamma\left(\mathrm{Ca}_{\mathrm{V}} \gamma\right)$. So far, 10 channel-forming $\mathrm{Ca}_{\mathrm{V}} \alpha$ subunits, encoded by distinct genes, have been identified. ${ }^{2}$ 
These $\mathrm{Ca}_{\mathrm{V}} \alpha$ subunits consist of four homologous transmembrane regions, and each is composed of six transmembrane domains linked by intracellular loops and amino and carboxy termini. The diversified physiological and pharmacological properties of VGCC are mainly derived from the existence of these $\mathrm{Ca}_{\mathrm{V}} \alpha$ subunits. Four $\mathrm{Ca}_{\mathrm{V}} \beta$ subunits have been identified so far. They all have alternative splicing variants. ${ }^{3} \mathrm{The}_{\mathrm{Ca}} \beta$ subunits are entirely intracellular, phosphorylated by multiple protein kinases, including protein kinase $\mathrm{C}$ and cAMP-dependent protein kinase, and they play a critical role in cell surface expression and modulating the gating properties of the $\mathrm{Ca}_{\mathrm{V}} \alpha$ subunit. ${ }^{4}$ Four distinctive $\mathrm{Ca}_{\mathrm{V}} \alpha 2 \delta$ genes, $\mathrm{Ca}_{\mathrm{v}} \alpha_{2} \delta_{1}, \mathrm{Ca}_{\mathrm{v}} \alpha_{2} \delta_{2}, \mathrm{Ca}_{\mathrm{v}} \alpha_{2} \delta_{3}$, and $\mathrm{Ca}_{\mathrm{v}} \alpha_{2} \delta_{4}$ have been identified. ${ }^{5,6}$ Their products and splice variants have specific tissue distribution patterns. ${ }^{6-9}$ The $\mathrm{Ca}_{\mathrm{v}} \alpha 2 \delta$ subunit consists of two disulfide-linked peptides $\left(\alpha_{2}\right.$ and $\delta$ ) that are encoded by the same gene. ${ }^{10,11}$ It is highly glycosylated and mainly extracellular, with a single transmembrane domain and five intracellular carboxyl terminal amino acids. ${ }^{12-14}$ Data from in vitro studies have shown that co-expression of $\mathrm{Ca}_{\mathrm{V}} \alpha 2 \delta$ with other calcium channel subunits increases and stabilizes current amplitude, ${ }^{13,15-20}$ channel binding sites, and binding affinity for N-type VGCC ligands. ${ }^{19,21}$ Three-dimensional structural analysis of the L-type VGCC by electron cryo-microscopy has indicated that the extracellular $\mathrm{Ca}_{\mathrm{V}} \alpha_{2}$ subunit protrudes from the membrane in close proximity to the channel forming $\mathrm{Ca}_{\mathrm{V}} \alpha$ subunit. ${ }^{22}$ Recent findings have indicated that the $\mathrm{Ca}_{\mathrm{V}} \alpha 2 \delta$ subunit is also involved in cellular trafficking of the calcium channel complex. ${ }^{23,24}$ These findings suggest that the $\mathrm{Ca}_{\mathrm{V}} \alpha 2 \delta$ subunit is likely involved in VGCC assembly and stabilization, modulation of $\mathrm{Ca}_{\mathrm{V}} \alpha$ subunit functions, and ligand binding. The $\mathrm{Ca}_{\mathrm{V}} \gamma 1$ subunit is a structural component for the skeletal muscle L-type calcium channels. ${ }^{25-27}$ Whether other identified $\mathrm{Ca}_{\mathrm{V}} \gamma$ or $\mathrm{Ca}_{\mathrm{V}} \gamma$-like subunits associate with other types of VGCC remained to be confirmed. ${ }^{28-32}$ The functional role of the $\mathrm{Ca}_{\mathrm{V}} \gamma$ subunit is not well understood.

Based on their physiological and pharmacological properties, VGCC can be subdivided into low voltage-activated T-type $\left(\mathrm{Ca}_{\mathrm{v}} 3.1, \mathrm{Ca}_{\mathrm{v}} 3.2\right.$, and $\left.\mathrm{Ca}_{\mathrm{v}} 3.3\right)$, and high voltageactivated L- $\left(\mathrm{Ca}_{\mathrm{v}} 1.1\right.$ through $\left.\mathrm{Ca}_{\mathrm{v}} 1.4\right), \mathrm{N}-\left(\mathrm{Ca}_{\mathrm{v}} 2.2\right)$, P/Q$\left(\mathrm{Ca}_{\mathrm{v}} 2.1\right)$, and $\mathrm{R}-\left(\mathrm{Ca}_{\mathrm{v}} 2.3\right)$ types, depending on the channelforming $\mathrm{Ca}_{\mathrm{V}} \alpha$ subunits. ${ }^{2,33}$ All of these five subclasses of calcium channels are found in the central and peripheral nervous systems. ${ }^{33}$ Regulation of intracellular calcium through activation of these VGCC plays obligatory roles in: 1) neurotransmitter release, 2) membrane depolarization and hyperpolarization, 3) enzyme activation and inactivation, and 4) gene regulation. ${ }^{34-40} \mathrm{~A}$ large body of data has clearly indicated that VGCC are implicated in mediating various disease states, ${ }^{38,41}$ including pain processing. ${ }^{40,42-45}$ This review focuses on recent preclinical and clinical studies regarding VGCC as targets for chronic pain management, especially neuropathic pain management. For more generalized reviews about the biophysical properties, and plasticity of VGCC on other disease states, the readers are referred to other recent reviews. ${ }^{46,47}$

\section{CALCIUM CHANNEL DRUGS FOR PAIN MANAGEMENT}

The diversities in biophysical properties and tissuespecific expression of VGCC thus become an important issue in drug specificity and safety in developing analgesic drugs for pain management. Data from preclinical studies have indicated that most neurons, including sensory neurons ${ }^{48}$ and spinal dorsal horn neurons, ${ }^{49-51}$ express multiple types of VGCC. Several types of VGCC are considered potential targets for analgesics based on their distribution, biophysical/pathological roles, and plasticity under pain-inducing conditions. ${ }^{52} \mathrm{We}$ aim here to highlight both preclinical and clinical advances in VGCC drug use, including combinational therapies, in pain medicine. A summary of the current VGCC medications that are commonly used for pain management is available in Table 1. The U.S. Food and Drug Administration (FDA)-approved indications for each are noted. A summary of ongoing clinical trials, as listed on clinicaltrials.gov, is available in Table 2, which provides the reader with information regarding studies using these common VGCC drugs to treat nonFDA-approved pain etiologies and indications.

\section{N-type VGCC blockers}

N-type VGCC are highly expressed in dorsal root ganglion (DRG) cell bodies and at the presynaptic terminals where afferent sensory fibers form synapses with postsynaptic dorsal horn neurons, ${ }^{47,53-55}$ implying an important role of these calcium channels in mediating normal sensory neuron excitability and neurotransmitter release. Changes in the biophysical properties and enhanced expression of these VGCC under pain-inducing pathological conditions would likely enhance synaptic vesicle release of pain-inducing transmitters, such as glutamate, substance $P$, and calcitonin gene-related peptide on stimulation that could activate interneurons and projection neurons, altering sensory excitability and leading to pain sensations. In addition, N-type VGCC are unique in that they are a target for descending activation of adrenergic pathways by norepinephrine ${ }^{56}$ and for inhibition by opioid pathways. ${ }^{57,58} \mathrm{~A}$ role for N-type VGCC in neuropathic pain is solidified by findings indicating that spinally delivered $\mathrm{N}$-type calcium channel antagonist can block nerve injury-induced tactile allodynia, ${ }^{59}$ and dorsal horn neuronal responses. ${ }^{50}$ Evidently, blocking the Ntype VGCC at the levels of spinal cord and sensory neurons results in inhibition of stimulus-evoked release of pain-inducing peptides, such as substance $\mathrm{P}$, calcito- 
Table 1. Summary of Current Calcium-Channel Drugs in Common Clinical Use for Pain Management

\begin{tabular}{|c|c|c|c|}
\hline Drug & FDA Indications & Adverse Reactions & Reference \\
\hline Gabapentin & $\begin{array}{l}\text { 2002: Postherpetic neuralgia; } \\
\text { 1994: epilepsy (partial } \\
\text { seizures), pediatric partial } \\
\text { seizures }\end{array}$ & $\begin{array}{l}\text { Dizziness, somnolence, peripheral edema, } \\
\text { nausea, dyspepsia, increased appetite, } \\
\text { constipation }\end{array}$ & $\begin{array}{l}\text { http://www.accessdata.fda.gov/ } \\
\text { drugsatfda_docs/label/2009/ } \\
\text { 020235s041,020882s028, } \\
\text { 021129s027lbl.pdf }\end{array}$ \\
\hline Pregabalin & $\begin{array}{l}\text { 2004: Neuropathic pain } \\
\text { associated with diabetic } \\
\text { peripheral neuropathy; } \\
\text { postherpetic neuralgia; } \\
\text { adjunctive therapy for adult } \\
\text { patients with partial onset } \\
\text { seizures; fibromyalgia }\end{array}$ & $\begin{array}{l}\text { Dizziness, somnolence, dry mouth, } \\
\text { edema, blurred vision, weight gain, } \\
\text { abnormal thinking (difficulty with } \\
\text { concentration/attention) }\end{array}$ & $\begin{array}{l}\text { http://www.accessdata.fda.gov/ } \\
\text { drugsatfda_docs/label/2009/ } \\
\text { 021446s013s014lbl.pdf }\end{array}$ \\
\hline Ziconotide & $\begin{array}{l}\text { 2004: Management of severe } \\
\text { chronic pain in patients for } \\
\text { whom intrathecal therapy is } \\
\text { warranted, and who are } \\
\text { intolerant or refractory to other } \\
\text { treatment, such as systemic } \\
\text { analgesics, adjunctive } \\
\text { therapies, or IT morphine }\end{array}$ & $\begin{array}{l}\text { Vertigo, vision blurred, asthenia, } \\
\text { abnormal gait, pyrexia, rigors, sinusitis, } \\
\text { anorexia, muscle spasms, pain in limb, } \\
\text { amnesia, ataxia, dizziness, dysarthria, } \\
\text { dysgeusia, headache, memory } \\
\text { impairment, nausea, nystagmus, } \\
\text { somnolence, tremor, anxiety, confusion, } \\
\text { insomnia, urinary retention, pruritus, } \\
\text { increased sweating }\end{array}$ & $\begin{array}{l}\text { http://www.accessdata.fda.gov/ } \\
\text { drugsatfda_docs/label/2007/ } \\
\text { 021060s003lbl.pdf }\end{array}$ \\
\hline
\end{tabular}

FDA $=$ U.S. Food and Drug Administration; IT = intrathecal.

nin gene-related peptide, and excitatory neurotransmitter, glutamate. ${ }^{43,60-62}$ Nerve or tissue injury-induced tactile allodynia and thermal hyperalgesia, but not acute pain states, are suppressed in mice lacking the N-type calcium channel-forming $\mathrm{Ca}_{\mathrm{V}} \alpha$ subunit. ${ }^{63-65}$ This implies that the N-type VGCC are more directly involved in chronic, rather than acute, nociception. This is consistent with data from direct blockade of N-type VGCC by cone snail peptides $\omega$-conotonix-GVIA and $\omega$-conotonixMVIIA (ziconotide or Prialt) that leads to inhibition of neuropathic and inflammatory pain, but not acute pain, in animal models. ${ }^{52}$ Interestingly, splicing variants of the N-type VGCC have been identified in sensory neurons. ${ }^{66-68}$ With validation of their functional contribution to pain processing, these subtypes of N-type VGCC could be potential targets for specific analgesic drugs.

\section{Peptide N-type VGCC blockers}

The FDA approval of ziconotide, or the synthetic version of $\omega$-conotonix-MVIIA (also called SNX-111, or Prialt (Elan Pharmaceuticals, Inc., San Diego, CA), for the treatment of chronic severe pain refractory to other current pain medications in December 2004 in the United States and in Europe ${ }^{69}$ (Table 1) marked the first clinical application of N-type VGCC peptide blockers in chronic pain management. $\omega$-conotonix-MVIIA is a 25 -amino acid peptide isolated from the marine fish-hunting cone snail, Conus magus. ${ }^{70}$ Due to the peptidergic nature of this drug, it is only approved for intrathecal application. Ziconotide can block N-type VGCC currents with high potency, but in a reversible manner. ${ }^{71,72}$ Data from preclinical studies have indicated that blocking N-type
VGCC by this toxin leads to diminished neurotransmitter release in the spinal cord, ${ }^{73}$ and diminished postoperative, inflammatory, and neuropathic pain states in animal models. ${ }^{59,74-76}$ The analgesic effect of intrathecal ziconotide is more potent and longer lasting than intrathecal morphine without tolerance or cross-tolerance to morphine analgesia. ${ }^{74,75}$

Clinical trials of intrathecal application of this peptide drug result in significant pain relief for patients with severe chronic pain (Table 2), including neuropathic pain and pain secondary to cancer or AIDS. Several reviews summarizing the details of some early clinical trials were recently published. ${ }^{77-79}$ Briefly, the first randomized, double-blind, placebo-controlled pilot study for pain relief with intrathecal ziconotide was in patients undergoing surgery. ${ }^{80}$ Patients received either a placebo or one of two intrathecal ziconotide doses $(0.7 \mu \mathrm{g} / \mathrm{h}$ and $7.0 \mu \mathrm{g} / \mathrm{h})$ postoperatively during the following $48 \mathrm{~h}$. The mean daily morphine consumption from patient-controlled administration in the 24- to 48 -h period was significantly lower in patients receiving ziconotide than in placebocontrolled patients. Pain scores in both ziconotide groups were lower than in the placebo group. Adverse events were more frequent on the higher ziconotide dose. In an open-label clinical study, ${ }^{81} 31$ male patients with chronic pain who had failed opioid management received continuous intrathecal ziconotide infusions. The average pain reduction was $43 \%$ in 19 out of 24 patients who completed the study. The concomitant use of opioids was reduced by at least $50 \%$ in 15 patients. Two multicenter, randomized, double-blind, placebo-controlled trials in 
Table 2. Summary of Clinical Trials by Pain Etiology*

\begin{tabular}{|c|c|}
\hline Study Drug & Study Indication \\
\hline Ziconotide, nimodipine, pregabalin & AIDS/HIV \\
\hline Pregabalin & Anxiety, preoperative \\
\hline Ziconotide, gabapentin, lamotrigine, pregabalin & Cancer \\
\hline $\begin{array}{l}\text { Amlodopine, gabapentin, ziconotide, nifedipine, } \\
\text { pregabalin, eperisone }\end{array}$ & $\begin{array}{l}\text { Chronic pain syndromes (pelvic, chronic prostatitis, abdominal, } \\
\text { chronic pain secondary to trauma, chronic low back pain, } \\
\text { chronic pancreatitis, vulvodynia) }\end{array}$ \\
\hline Verapamil & Cluster headache \\
\hline Pregabalin & Complex regional pain syndrome \\
\hline Pregabalin & Essential tremor \\
\hline Lamotrigine, pregabalin & Facial pain (excluding postherpetic neuralgia) \\
\hline Gabapentin, pregabalin & Fibromyalgia \\
\hline Diltiazem & Hemorrhoidectomy \\
\hline Gabapentin, pregabalin & Multiple sclerosis \\
\hline Gabapentin, gabapentin XR, pregabalin, lamotrigine & $\begin{array}{l}\text { Peripheral neuropathy (chemotherapy, radiation, alcohol, } \\
\text { diabetic, vascular, idiopathic) }\end{array}$ \\
\hline Gabapentin & Phantom limb pain \\
\hline Gabapentin, gabapentin XR, lamotrigine, pregabalin & Postherpetic neuralgia \\
\hline Gabapentin, pregabalin & $\begin{array}{l}\text { Postoperative pain (sternotomy, thoracotomy, hip surgery, joint } \\
\text { replacement, cesarean section, tonsillectomy, keratectomy, } \\
\text { inguinal hernia repair, spinal fusion, knee arthroscopy, } \\
\text { scoliosis surgery, CABG, hysterectomy, cholecystectomy, } \\
\text { mastectomy, axillary node dissection, bunionectomy) }\end{array}$ \\
\hline Pregabalin & Post-traumatic pain \\
\hline Pregabalin & Radiculopathy \\
\hline Pregabalin & Spinal cord injury \\
\hline Pregabalin & Spinal stenosis \\
\hline Pregabalin & Stroke \\
\hline Gabapentin & Stump pain \\
\hline Gabapentin & Tinnitus \\
\hline Lamotrigine & Trigeminal neuralgia \\
\hline
\end{tabular}

*Source: clinicaltrials.gov.

patients with chronic cancer or AIDS-associated pain ("malignant pain") ${ }^{82}$ or with nonmalignant pain ${ }^{83}$ were conducted. In the "malignant," chronic cancer/AIDS-related pain trial, ${ }^{82}$ ziconotide improved the mean visual analog scale of pain intensity (VASPI) scores by $53 \%$. In addition, 53\% patients in the ziconotide group had pain relief classified as moderate to complete compared with $18 \%$ patients in the placebo group. Five patients in the ziconotide group had achieved "complete" pain relief. In the "nonmalignant" pain trial, ${ }^{83} 240$ patients were randomized to ziconotide versus a placebo. Ziconotide reduced the mean VASPI scores by $31 \%$ (compared with $6 \%$ for the placebo group). In addition, more than $43 \%$ of patients in the ziconotide group had moderate-to-complete analgesia, compared with $17 \%$ in the placebo group.

Several additional studies published in 2006 assessed the ideal effective dose and tolerability of ziconotide. In three well-designed trials with up to 21-day durations, ${ }^{84}$ titration of ziconotide resulted in significant improvement in the VASPI scores for chronic malignant or nonmalignant pain compared with a placebo. The analgesic effects of ziconotide remained for up to 12 months in long-term, open-label trials. In addition, lower incidence and severity of adverse effects were observed in patients with low initial doses and gradual titration to achieve analgesia. In a randomized, double-blind, placebo-controlled study, ${ }^{85}$ slower titration of intrathecal ziconotide to a lower maximum dose was associated with a significant improvement in pain relief and was better tolerated compared with faster titrations and higher maximum mean dose reported in two earlier placebo-controlled trials. It was suggested that administration of intrathecal ziconotide at a low starting (maximum) dose of $0.5 \mu \mathrm{g} /$ day and a limitation of dose escalations to no more than $0.5 \mu \mathrm{g} /$ day may limit adverse effects. ${ }^{86}$

A recent case report highlighted the use of ziconotide in a patient with recalcitrant pain post-spinal cord injury, with both at-level and below-the-neurological-level of neuropathic pain syndromes. When intrathecal hydromorphone was used as a treatment modality, the patient's at-level, but not the below-level, pain was reduced. Conversely, when intrathecal ziconotide was administered, analgesia was positive for the below-level, but only minimally for the at-level, pain. When combination therapy with intrathecal hydromorphone and ziconotide was used, analgesia was sufficient for both pain components. This study implies that central pain due to spinal cord 
injury may be an indication for intrathecal ziconotide, particularly in combination with intrathecal opioids. ${ }^{87}$

The usage of this peptide drug is limited by the route of administration and undesirable side effects, including sedation, dizziness, nausea, emesis, somnolence, headache, confusion, memory impairment, slurred speech, nystagmus, double or blurry vision, urinary retention, hypotension, elevated creatine kinase levels, and gait abnormality. ${ }^{78,88-90}$ It is believed that the serious side effects of ziconotide are derived from complete blockade of the N-type VGCC that would affect the normal biophysical functions of widely distributed N-type VGCC. ${ }^{91}$ However, it is argued that more convincing data are needed to make definitive conclusions because similar adverse effects are not detectable in N-type VGCC knockout mice, which have no detectable evidence of developmental compensation from other types of VGCC. ${ }^{89}$ It is possible that some of these adverse effects may be secondary to effects at other receptors besides the N-type VGCC. Most adverse events occur during the first week of treatment. After 6 months of treatment, the incidence of adverse events is noted to be 0 to $35 \%$ of that reported in the first month of treatment. ${ }^{84}$ Potential contamination of intrathecal pump devices used to administer ziconotide (or any other intrathecal agent) may increase the risk of meningitis. ${ }^{77}$ The neurological side effects of ziconotide dictate that the drug should be used with caution and careful dose titration. Particular symptoms may correlate with the rate of infusion. ${ }^{90}$ Because addiction and tolerance are not detectable with the analgesic effects of ziconotide, ${ }^{88}$ but are often observed with the use of opioid analgesics, intrathecal ziconotide could be an option for replacing intrathecal morphine for chronic severe pain relief. However, the combination of opioid withdrawal symptoms and the cognitive/psychiatric adverse effects of ziconotide could make the conversion challenging. Successful treatment with ziconotide monotherapy has been suggested to include physician and psychological supports to decrease possible adverse psychological and physiological complications. ${ }^{92}$

Overall, although pain relief by ziconotide is accompanied with some adverse effects, use of this analgesic has several benefits. Ziconotide is less mood-altering than morphine for comparable analgesia and has the advantage of lacking addiction, opioid-induced hyperalgesia, and other systematic effects commonly observed with opioids. ${ }^{93}$ For these reasons, the Polyanalgesic Consensus Conference of 2007 puts ziconotide in the first line of intrathecal therapy management, along with morphine and hydromorphone, in its recommended algorithm for nociceptive, mixed, and neuropathic pain. ${ }^{94}$ As summarized in a recent review, the evidence for shortterm improvement of malignancy-related pain or neuropathic pain with intrathecal ziconotide is also strong. ${ }^{95}$
Nevertheless, searching for safer analgesic peptide antagonists against the N-type VGCC continues. It has been reported that $\omega$-conotonix-GVIA, a 27-amino acid peptide isolated from the cone snail, Conus geographus, also exhibits analgesic properties in animal models. ${ }^{52}$ In contrast to ziconotide, $\omega$-conotonix-GVIA is an irreversible inhibitor of N-type VGCC, ${ }^{96}$ which precludes its clinical application due to potential severe side effects. However, recent studies have indicated that binding of this toxin peptide to the N-type VGCC can also modulate (inhibit) N-type VGCC gating properties so that approximately $50 \%$, instead of a complete blockade, of the calcium influx during an action potential is inhibited, ${ }^{91}$ in addition to the primary pore blocking mechanism. This would provide a means to normalize elevated (activated) N-type VGCC activities in a disease condition, such as chronic pain, but preserve the biophysical functions of N-type VGCC in maintaining normal physiological functions, and thus reduce adverse side effects. Highthroughput screening using a scintillation proximity assay has been used to search for small molecules that can displace $\omega$-conotonix-GVIA binding to the N-type VGCC in an attempt to find N-type VGCC modulators with high affinity to the $\omega$-conotonix-GVIA binding sites on the N-type VGCC. ${ }^{97}$

Another 27-amino acid peptide $\omega$-conotonix-CVID, also called AM336, from the cone snail, Conus catus, is perhaps the most selective of all N-type VGCC peptide blockers with greater than 24 hours of analgesia observed in rats from subnanomolar intrathecal doses. ${ }^{73,98,99}$ Intrathecal administration of this peptide drug into rat pain models results in inhibition of spinal release of paininducing peptides and potent dose-dependent anti-nociception. ${ }^{73,98}$ In addition, AM336 showed a greater ratio of analgesic efficacy to behavioral toxicity than ziconotide ${ }^{73,98}$ probably due to its greater selectivity for $\mathrm{N}$-type in comparison with $\mathrm{P} / \mathrm{Q}$ type VGCC. ${ }^{71}$ This peptide drug was assessed in a phase I clinical trial in oncology patients with severe pain ${ }^{100}$ and its efficacy was established in a small phase IIa clinical trial for patients with severe cancer pain. ${ }^{40}$ Unfortunately, the side effects were undesirable and dose limiting. The adverse effect profile is surprising given the $10^{6}$-fold binding selectivity of this peptide for N-type in comparison with P/Q-type VGCC, ${ }^{71}$ and it may be secondary to supraspinal effects.

\section{Small molecule N-type VGCC blockers}

The potency of ziconotide in chronic pain relief, and its association with an undesirable administration route and an undesirable side-effect profile, has prompted a race in searching for small molecules that would be orally active and have an acceptable therapeutic window for chronic pain management. Using a high-throughput fluorescence-based in vitro assay to compare $\mathrm{IC}_{50}$ values of blocking both N-type and L-type VGCC in a human 
neuroblastoma cell line for identifying specific N-type VGCC blockers from its corporate compound library, scientists in Ionix Pharmaceuticals Ltd. have developed a series of new N-type VGCC blockers derived from structural modifications of "hit" structures. ${ }^{101}$ After structural and activity relationship analysis, compounds with up to 30-fold of N-type/L-type VGCC selectivity and up to 0.2 $\mu \mathrm{M}$ in $\mathrm{IC}_{50}$ values are identified. Unfortunately, analgesic efficacies in chronic pain models were not included in the study. Further investigations for the analgesic efficacy and toxicity in animal pain models may prove the usefulness of these compounds for further development as therapeutic agents for chronic pain management.

\section{Indirect inhibitors of $\mathrm{N}$-type channels}

$\mathrm{N}$-type VGCC can be modulated by morphine, an important analgesic. Binding of morphine to $\mu$-opioid receptors activates $G_{\beta \gamma}$ which translocates to the membrane and binds to the N-type VGCC. A massive G-protein-dependent inhibition of calcium currents results in an inhibition of neurotransmitter release, ${ }^{2,45,102}$ and reduces the ability of the DRG sensory neurons to propagate pain signals. This process is at least partially responsible for morphine's analgesic effect, but can also contribute to tolerance development. Combination of ziconotide with $\mu$-opioids shows synergistic analgesia when administered intrathecally. ${ }^{74,98,103}$ This combination therapy may help to reduce opioid tolerance, a poor side-effect profile, and the potential for opioid-induced hyperalgesia, all of which limit the long-term usefulness of $\mu$-opioid receptor agonists in pain medicine. Spinal noradrenaline can reduce VGCC-mediated transmission by presynaptic and postsynaptic inhibition, and by $\alpha 1$ adrenoceptor-mediated activation of inhibitory interneurons. ${ }^{40}$ These may explain the effectiveness of $\alpha 2$-adrenergic agonists (such as clonidine) and nonselective small molecule norepinephrine transporter (NET) inhibitors (such as duloxetine) in pain relief. However, these medications also have limiting side-effect profiles. ${ }^{104}$ Highly selective NET inhibitors, $\chi$-conopeptides, have been isolated from the cone snail, Conus marmoreus. ${ }^{105}$ It was demonstrated that the $\chi$-conopeptide NET-binding site partially overlaps the tricyclic antidepressant NET-binding site. ${ }^{106}$ Based on studies in rat neuropathic pain models, the $\chi$-conopeptide compound MrIA (Xen2174) was found to produce strong anti-allodynic effects without significant side effects after intrathecal administration. ${ }^{107}$ A phase I/IIa clinical trial involving intrathecal evaluation of Xen2174 in cancer patients with intractable pain shows initial promising results. ${ }^{40}$ This line of compounds may represent an important option in the search to identify a potentially different therapeutic approach in targeting VGCC for chronic pain management.

\section{Peptide T-type VGCC blockers}

Low-voltage T-type VGCC are found in DRG primary afferent cell bodies and in free nerve endings. They contribute to the initiation of the action potential in these locations by lowering the required threshold for activation. ${ }^{108}$ By promoting burst activity and synaptic excitation, enhanced T-type VGCC activity favors the development of pain. ${ }^{51,109}$ T-type VGCC density has been increased in rat neuropathic pain models of diabetic neuropathy and chronic constriction nerve injury. ${ }^{110,111}$ The facts that T-type VGCC knockout animals have hyposensitivity to pain and that intrathecal injection with Ttype VGCC blockers or antisense oligonucleotides results in reduced excitability of the primary afferents and therefore reduced nociceptive responses all attest to their established role in the processing of pain, especially neuropathic pain. ${ }^{51,112-118}$ However, the exact mechanisms underlying the role of T-type VGCC in nociception still remain elusive. Several regulatory mechanisms of T-type VGCC in pain processing have been proposed. These include redox modulation of T-type VGCC in rat peripheral nociceptors, ${ }^{119}$ and the selective enhancement of T-type VGCC in nociceptive DRG neurons by reducing agents, such as L-cysteine, synthetic, and endogenous chelators of zinc. ${ }^{119}$ The latter is supported by the findings that peripherally injected reducing agents produce thermal hyperalgesia in wild-type but not Cav3.2 knockout mice, indicating that T-type VGCC may have a special role in peripheral sensitization. ${ }^{119}$ Currently, ethosuximide is the only T-type VGCC blocker approved for human use. ${ }^{120}$

\section{L-type VGCC blockers}

Evidence from recent clinical studies shows that Ltype VGCC blockers, such as topiramate, are efficacious for neuropathic pain management, and leads to the suggestion that this medication should be a third-line agent for neuropathic pain treatment. ${ }^{121}$ In one study, topiramate has been shown to cause statistically significant reduction in pain intensity compared to a placebo, as measured on a $100-\mathrm{mm}$ visual analog scale, for up to 12 weeks in diabetic peripheral neuropathy patients. ${ }^{122}$ However, three other randomized, double-blind, placebo-controlled trials with more than 1,200 diabetic neuropathy patients failed to show statistically significant reductions in pain intensity after 18 to 22 weeks of treatment. In addition, these three studies also resulted in topiramate drop out rates ranging from $16 \%$ to $31 \%$ compared with $8 \%$ for a placebo. The most commonly reported adverse events were fatigue, paresthesias, nausea, somnolence, and diminished appetite. ${ }^{123}$ Another study evaluated the efficacy of topiramate for pain in patients associated with chronic lumbar radiculopathy and found modest pain relief in the topiramate-treated group, but with a $24 \%$ drop out rate. ${ }^{124}$ At least one 
recent case report has suggested that topiramate may be a useful pharmacologic modality for pain relief in patients with postherpetic neuralgia who have failed other agents. ${ }^{125}$ It has been reported that topiramate has other pharmacologic actions including blockage of voltagegated sodium channels in a dose-dependent manner, ${ }^{125}$ potentiation of GABA inhibition, and AMPA receptor blockade, ${ }^{122-124,126}$ which may contribute to both its analgesic potential and its adverse side effects.

\section{Other types of VGCC blockers}

Contribution of other types of VGCC to pain processing have been suggested in some preclinical studies. Missense mutations in the $\mathrm{Ca}_{\mathrm{v}} 2.1 \mathrm{P} / \mathrm{Q}$-type calcium channels lead to familial hemiplegic migraine, an inherited form of migraine with aura and hemiparesis. ${ }^{127-129}$ In addition, R-type VGCC have been implicated in the processing of neuropathic pain and other pain states. ${ }^{130}$ However, few clinical researches evaluating the efficacies of specific blockers to these VGCC in pain relief are available; thus, these are not covered in this review.

\section{CALCIUM CHANNEL $\alpha 2 \delta 1$ LIGANDS FOR PAIN MANAGEMENT}

The unique features of the $\mathrm{Ca}_{\mathrm{v}} \alpha_{2} \delta$ subunit and a large body of recent findings have suggested that the $\mathrm{Ca}_{\mathrm{v}} \alpha_{2} \delta_{1}$ subunit may play an important role in neuropathic pain development. Biochemical data have indicated a significant $\mathrm{Ca}_{\mathrm{v}} \alpha_{2} \delta_{1}$, but not $\mathrm{Ca}_{\mathrm{v}} \alpha_{2} \delta_{2}$, subunit upregulation in the spinal dorsal horn, and DRG after nerve injury ${ }^{23,131-135}$ that correlates with neuropathic pain development. ${ }^{131,132,136}$ In addition, blocking axonal transport of injury-induced DRG $\mathrm{Ca}_{\mathrm{v}} \alpha_{2} \delta_{1}$ subunit to the central presynaptic terminals diminishes tactile allodynia in nerve injured animals, suggesting that elevated DRG $\mathrm{Ca}_{\mathrm{v}} \alpha_{2} \delta_{1}$ subunit contributes to neuropathic allodynia, even though a postsynaptic mechanism can not be completely ruled out. $^{23,24,136}$ Interestingly, the $\mathrm{Ca}_{\mathrm{v}} \alpha_{2} \delta_{1}$ subunit (and the $\mathrm{Ca}_{\mathrm{v}} \alpha_{2} \delta_{2}$, but not $\mathrm{Ca}_{\mathrm{v}} \alpha_{2} \delta_{3}$ and $\mathrm{Ca}_{\mathrm{v}} \alpha_{2} \delta_{4}$, subunits) is the binding site for gabapentin, ${ }^{6,7,137}$ which has anti-allodynic/hyperalgesic properties in patients and animal models with unknown mechanisms. ${ }^{131,132,138-143} \mathrm{Be}-$ cause injury-induced $\mathrm{Ca}_{\mathrm{v}} \alpha_{2} \delta_{1}$ expression correlates with neuropathic pain development and maintenance, and various calcium channels are known to contribute to spinal synaptic neurotransmission ${ }^{50,144-149}$ and DRG neuron excitability, ${ }^{66,149-151}$ injury-induced $\mathrm{Ca}_{\mathrm{v}} \alpha_{2} \delta_{1}$ subunit upregulation may contribute to the initiation and maintenance of neuropathic pain by altering the properties and/or distribution of VGCC in the subpopulation of DRG neurons and their central terminals, therefore modulating excitability and/or synaptic neuroplasticity in the dorsal horn. This is supported by findings from preclinical studies indicating that intrathecal antisense oligonu- cleotides against the $\mathrm{Ca}_{\mathrm{v}} \alpha_{2} \delta_{1}$ subunit can block nerve injury-induced $\mathrm{Ca}_{\mathrm{v}} \alpha_{2} \delta_{1}$ upregulation and prevent the onset of allodynia ${ }^{152}$ and reserve established allodynia. ${ }^{136}$

Both gabapentin and pregabalin are structural derivatives of the inhibitory neurotransmitter GABA although they do not bind to $\mathrm{GABA}_{\mathrm{A}}, \mathrm{GABA}_{\mathrm{B}}$, or benzodiazepine receptors, or alter $\mathrm{GABA}$ regulation in animal brain preparations. ${ }^{153}$ Binding of gabapentin and pregabalin to the $\mathrm{Ca}_{\mathrm{v}} \alpha_{2} \delta_{1}$ subunit of VGCC results in a reduction in the calcium-dependent release of multiple neurotransmitters, ${ }^{121,154}$ leading to efficacy and tolerability for neuropathic pain management. ${ }^{121}$

\section{Gabapentin}

Gabapentin is approved by the FDA for postherpetic neuralgia, neuropathic pain, and partial seizures ${ }^{155-157}$ (Table 1). Several studies also suggest a clinical role for restless leg syndrome, ${ }^{158}$ general anxiety, ${ }^{159}$ and general neuropathic pain. ${ }^{141}$ In common practice, gabapentin is used as a first-line agent to treat neuropathic pain from central origin (such as stroke or spinal cord injury) or from peripheral origin (such as peripheral neuropathy or radiculopathy). Despite its role and ubiquity, several controlled trials demonstrate a low responder rate of approximately $32 \%$. $^{155}$

Gabapentin has inherent pharmacokinetic limitations; the half-life of gabapentin is short, and therefore administration must be frequent. In addition, gabapentin is absorbed actively via absorption pumps located in the upper gastrointestinal tract. Therefore, conventional sustained-release formulations, where drug release is prolonged and occurs throughout the gastrointestinal tract, would simply decrease the bioavailability of the drug. ${ }^{160}$ Therapeutic doses and responses vary among patients and prediction of the ultimate desired doses is exceedingly difficult. Furthermore, most gabapentin absorption is nonlinear (i.e., as the dose is increased, the bioavailability decreases). ${ }^{160-162}$

The FDA has approved gabapentin at a dose of up to $1,800 \mathrm{mg} / \mathrm{day}$. This drug is frequently used off-label for the treatment of other neuropathic pain conditions, including painful diabetic peripheral neuropathy and radiculopathy, at higher doses up to $3,600 \mathrm{mg} /$ day. ${ }^{141,163,164} \mathrm{It}$ has been suggested that gabapentin may be effective for the treatment of chronic pain of any etiology, including musculoskeletal headache, cervical pain, neuropathic pain, lumbar pain, or multiple pains, such as fibromyalgia $^{165,166}$ (Table 2). Although gabapentin is well tolerated in studies, a statistically significant incidence of sedation, lightheadedness, and dizziness is noted when compared to control patients. ${ }^{166}$

Combinational treatment of gabapentin with other pain medications for pain management has been tested in numerous clinical trials. Combination treatment of gabapentin and morphine in an animal model of neuropathic 
pain results in a significant increase in the inhibitory effect of morphine on the dorsal horn neural response to peripheral stimulation, ${ }^{167}$ providing preclinical evidences to support that combination therapies with gabapentin may have clinical benefits in chronic pain management. A crossover study involving 57 patients with neuropathic pain demonstrated improved clinical outcomes when patients received a combination of morphine and gabapentin versus monotherapy. ${ }^{168}$ A larger study with 338 patients demonstrated that co-administration of gabapentin and prolonged-release of oxycodone has a clinically meaningful effect in patients with painful (diabetic) neuropathy. ${ }^{169}$

\section{Gabapentin extended-release}

A gabapentin extended-release (ER) has been developed. Gabapentin ER was constructed using polymerbased AcuForm technology (Depomed, Inc., Menlo Park, CA). When taken with a meal, the tablet is retained in the stomach for up to $8 \mathrm{~h}$ and the drug is gradually released over $10 \mathrm{~h}$ to the small intestine, its optimal site of absorption. ${ }^{162,170}$ This prolonged release was designed to provide similar or improved systemic exposure as compared with the immediate release formulation.

In an exploratory study, the daily exposure provided by less frequent gabapentin extended-release dosing (once- and twice-daily) was found not to be statistically different from that provided by gabapentin immediaterelease, administered more frequently (three times a day [TID]). Gabapentin ER once-daily dosing was found to produce higher maximum plasma concentrations compared with the TID gabapentin immediate-release regimen and twice-daily gabapentin ER dosing was found to result in less fluctuation in plasma concentrations. ${ }^{171}$

A recent randomized, double-blinded, placebo-controlled study evaluated gastric-retentive gabapentin in 158 individuals who had chronic pain from post-herpetic neuralgia for at least 3 months. Patients were given 1,800 $\mathrm{mg}$ gabapentin ER once daily in the afternoon or $600 \mathrm{mg}$ in the morning with $1,200 \mathrm{mg}$ in the afternoon (twicedaily dosing) or placebo. Efficacy outcomes included changes from baseline on the pain intensity numeric rating scale (average daily pain) and average daily sleep interference score. The authors found statistically significant reductions in pain scores at all time points and as early as week 1 post-treatment in the gabapentin ER twice-daily group compared with the placebo group. But there was no significant reduction in pain scores in the once-daily gabapentin ER group compared with the placebo control, although a trend was noted. It was concluded that although ideal, once-daily gabapentin ER dosing may result in plasma levels that fall below the therapeutic range before the end of the 24-hour dosing period. Overall, the proportion of responders with at least a $50 \%$ reduction in pain score in the gabapentin ER twice-daily group (28.8\%) was comparable with that reported in the immediate-release gabapentin studies $(32.2 \%)^{156}$ and in the pregabalin studies $(150 \mathrm{mg} / \mathrm{day}$, three times a day [26\%], or $300 \mathrm{mg} /$ day three times a day [28\%]). ${ }^{172}$ The incidence of adverse events was not statistically different between the placebo group and either of the gabapentin ER groups (once- or twice-daily), and it did not appear to be dose-dependent. ${ }^{173}$

\section{XP13512: Gabapentin enacarbil}

A novel pro-drug of gabapentin, XP13512/GSK $1838262 \quad(( \pm)-1-([(\alpha$-isobutanoyloxyethoxy)carbonyl $]-$ aminomethyl)-1-cyclohexane acetic acid) was recently developed. This drug has enhanced absorption in the large intestine, allowing an extended-release formulation. ${ }^{174}$ Four clinical studies (two immediate-release [IR] formulation studies and two extended-release [XR] formulation studies) have evaluated the bioavailability of the drug. In the first IR study, XP13512 was administered to healthy adults. Five groups of 10 subjects were randomized to receive the pro-drug or placebo in a double-blind fashion with five ascending pro-drug/placebo doses $(200,400,800,1,200$, and 1,400 mg). Maximum blood gabapentin concentrations were noted at $2.5 \mathrm{~h}$ postadministration. Bioavailability was consistently high $(>67 \%)$ across all doses. In the second IR study, twice daily dosing (350 mg-2,100 mg) was given. Steady state concentrations of XP13512 were found proportional to the oral dose range. In addition, the bioavailability of gabapentin from XP13512 was consistently high $(>72 \%)$ across the dose range. Blood concentrations of the intact pro-drug after oral dosing were low. In the first XR study, plasma exposure to gabapentin was higher post-XR treatment than after an equimolar dose of oral gabapentin. The time to maximum concentration ( $\mathrm{T}$ max) of gabapentin was substantially greater in the subjects given XP13512 than in subjects given oral gabapentin. In another XR study, plasma gabapentin was proportional to the XP13512 dose over the range studied (300 mg-1200 mg); bioavailability was increased in the presence of food. Sustained delivery was noted at all dose levels. Overall, both IR and XR formulations of XP13512 were well tolerated without serious adverse events. Minor adverse events reported included dizziness, headache, and sedation. Minor event reporting was similar for oral gabapentin, except for increased dizziness in the IR formulation of XP13512, perhaps due to rapid absorption. The XR formulation, although with higher peak gabapentin concentrations than oral gabapentin, actually had similar adverse events compared with oral gabapentin. ${ }^{174}$

Given its increased absorption and more predictable gabapentin exposure, its reduced inter-patient variability, and its reduced-dosing frequency, XP13512 may become an important option in our toolbox of upcoming neuro- 
pathic agents. This novel extended-release pro-drug would be ideal for patients requiring prolonged clinical exposure, such as patients with restless leg syndrome, using a single daily dose. Use of the XR formulation may dramatically improve treatment compliance.

GlaxoSmithKline announced results from a phase II clinical trial of XP13512 for painful diabetic neuropathy in adults in April 2009 (Phase II Results for GSK1838262 [XP13512] Reported for Neuropathic Pain Associated with Diabetic Peripheral Neuropathy; Medical News Today; article date, 4/29/2009; http://www. medicalnewstoday.com/articles/148026.php). There were 421 patients who were enrolled in a 14-week, doubleblind, placebo-controlled study and were randomized to receive either $1,200 \mathrm{mg} /$ day, $2,400 \mathrm{mg} /$ day, or 3,600 $\mathrm{mg}$ /day of XP13512 in divided doses twice-daily; 300 $\mathrm{mg} /$ day pregabalin as an active control in divided doses three times daily, or a placebo. The primary endpoint was a change from baseline on the Pain Intensity-Numerical Rating Scale (PI-NRS). Both the pregabalin active control and XP13512 failed to show a statistically significant benefit when compared with a placebo. These results may be due to an unusually high placebo response. Therefore, efficacy conclusions are difficult to draw. XP13512, at all doses, was well tolerated in the study. Dizziness and somnolence were the most common reported adverse events.

The efficacy of XP13512 was also recently tested in a randomized, double-blind, placebo-controlled study in a population of patients with moderate-to-severe primary restless leg syndrome. ${ }^{175}$ There were 222 patients who were randomized to $1,200 \mathrm{mg} /$ day of XP13512 oncedaily or a placebo, and 192 patients completed the study. At week 12, there was a greater improvement in international restless leg syndrome scores. Significant treatment effects were noted as early as 1 week, the earliest time point measured, in the treatment group. More patients treated with XP13512 $(76 \%)$ were responders compared with placebo (39\%) $(p<0.0001)$. The medication was generally well tolerated; mild-to-moderate side effects, including somnolence and dizziness were reported. ${ }^{175}$

\section{Pregabalin}

Pregabalin, S-enantiomer of racemic 3-isobutyl GABA, is a second-generation anticonvulsant and structurally similar to gabapentin. The binding affinity of pregabalin for the $\mathrm{Ca}_{\mathrm{v}} \alpha_{2} \delta_{1}$ subunit, however, is 6 times greater than that of gabapentin, which makes pregabalin more clinically effective at lower doses. ${ }^{176}$ Pregabalin is approved in the United States and Europe for the treatment of neuropathic pain associated with diabetic peripheral neuropathy and postherpetic neuralgia, and epilepsy as an add-on agent ${ }^{177-180}$ (Table 1). In addition, pregabalin was approved by the FDA in 2007 as the first drug for the treatment of fibromyalgia ${ }^{181}$ (Table 1).

Pregabalin is well tolerated, has predictable absorption across the gastrointestinal tract, and has minimal drugdrug interactions. ${ }^{182}$ Clinical trials have been conducted to examine the efficacy of pregabalin in other chronic pain conditions (Table 2). At least seven published prospective, randomized clinical trials have documented its efficacy in postherpetic neuralgia and painful diabetic peripheral neuropathy with improvements in pain intensity scores, decreased sleep interference, and secondary outcome improvements. ${ }^{182}$ The effects of pregabalin on patients with fibromyalgia are a current focus. These were first published in $2005^{183}$ in an 8-week multicenter efficacy and safety clinical trial. Pain intensity, sleep, fatigue, and quality of life were measured outcomes. Pregabalin (at $450 \mathrm{mg} /$ day) significantly reduced pain intensity on a 0 to 10 point scale as compared with a placebo ( $p \leq 0.001)$. Pregabalin (at doses of $300 \mathrm{mg} /$ day and $450 \mathrm{mg}$ /day) was reported to statistically improve sleep, fatigue, and global measures of change. At 450 $\mathrm{mg} /$ day, pregabalin also improved other secondary outcomes associated with health-related quality of life as measured in the Short Form-36 (SF-36) Health Survey. Adverse events were mostly mild, and the most frequently reported adverse events were dizziness and somnolence, although weight gain and peripheral edema were also reported. ${ }^{183}$

Pregabalin was also studied in combination therapy for pain management. It was used in a combinational treatment of fibromyalgia ${ }^{184}$ in an open-label, 12-week study in 19 female patients already receiving therapy with quetiapine ( $76 \mathrm{mg} /$ day). At the dose range from $75 \mathrm{mg} /$ day to $300 \mathrm{mg} /$ day, depending on the patient's tolerability, pregabalin was found to statistically improve the physical component of the SF-12 Health Survey, as well as the pain and tiredness in the awakening subscales of the fibromyalgia impact questionnaire. Six of 19 patients withdrew from the study, including 3 of them due to side effects. ${ }^{184}$

A multicenter study involving more than 700 patients evaluated the efficacy and safety of pregabalin in patients with fibromyalgia. ${ }^{185}$ Patients were given 300,450 , or $600 \mathrm{mg} /$ day in twice-daily dosing schedules for 13 weeks. All patients treated with pregabalin had statistically improved pain scores and patient global impression of change scores as compared with placebo treatments. Statistically significant improvements in secondary outcomes measuring sleep were also reported. Side effects were mild to moderate and the most frequently reported side effects were dizziness, somnolence, headache, infection, and weight gain. This efficacy and safety was similarly documented in another recently published trial. ${ }^{186} \mathrm{~A}$ recent long-term multicenter double-blind, placebo-controlled randomized discontinuation trial (FREEDOM) in the fibro- 
myalgia population demonstrated the durability (maintenance of response with pregabalin treatment relative to placebo) of pregabalin for this indication. ${ }^{187}$ In this trial, individually-determined optimal pregabalin doses were determined with the hypothesis that the therapeutic response would persist longer. The trial included a 6-week, open-label pregabalin-treatment phase followed by a 26week, double-blinded treatment with pregabalin or a placebo. Patients treated with pregabalin had significantly delayed time to loss of therapeutic response, defined as $<30 \%$ reduction in pain from open-label baseline, versus patients receiving a placebo $(p<0.0001)$. Half of the placebo group had loss of therapeutic response by day 19 , but half of the pregabalin group retained therapeutic effect and had not lost response by the end of the trial. At the end of the 26-week, double-blind treatment phase, $61 \%$ of the placebo patients met loss of therapeutic response criteria versus $32 \%$ of pregabalin-treated patients. One contemporary commentary proposes a fibromyalgia treatment strategy combining pregabalin with memantine in the clinical trial. ${ }^{188}$ The latter is proposed as an agent that may slow down the loss of cephalic gray matter commonly observed as a comorbidity in chronic pain states. $^{189-194}$

Acknowledgements: Supported in part by the National Institutes of Health, grant no. DE019298 (Z. D. Luo).

\section{REFERENCES}

1. Mitka M. "Virtual textbook" on pain developed: effort seeks to remedy gap in medical education. JAMA 2003;290:2395.

2. Catterall WA. Structure and regulation of voltage-gated $\mathrm{Ca} 2+$ channels. Annu Rev Cell Dev Biol 2000;16:521-555.

3. Dolphin AC. Beta subunits of voltage-gated calcium channels. J Bioenerg Biomembr 2003;35:599-620.

4. Dolphin AC. Beta subunits of voltage-gated calcium channels. J Bioenerg Biomembr 2003;35:599-620.

5. Klugbauer N, Lacinova L, Marais E, Hobom M, Hofmann F. Molecular diversity of the calcium channel a2d subunit. J Neurosci 1999;19:684-691.

6. Qin N, Yagel S, Momplaisir ML, Codd EE, D'Andrea MR. Molecular cloning and characterization of the human voltagegated calcium channel alpha(2)delta-4 subunit. Mol Pharmacol 2002;62:485-496.

7. Marais E, Klugbauer N, Hofmann F. Calcium channel alpha2delta subunits-structure and gabapentin binding. Mol Pharmacol 2001;59:1243-1248.

8. Kim HL, Kim H, Lee P, King RG, Chin H. Rat brain expresses an alternatively spliced form of the dihydropyridine-sensitive L-type calcium channel alpha 2 subunit. Proc Natl Acad Sci U S A 1992;89:3251-3255.

9. Angelotti T, Hofmann F. Tissue-specific expression of splice variants of the mouse voltage-gated calcium channel alpha2/delta subunit. Febs Letters 1996;397:331-337.

10. Ellis SB, Williams ME, Ways NR, et al. Sequence and expression of mRNAs encoding the alpha 1 and alpha 2 subunits of a DHPsensitive calcium channel. Science 1988;241:1661-1664.

11. De Jongh KS, Warner C, Catterall WA. Subunits of purified calcium channels. Alpha 2 and delta are encoded by the same gene. J Biol Chem 1990;265:14738-14741.

12. Brickley K, Campbell V, Berrow N, et al. Use of site-directed antibodies to probe the topography of the alpha 2 subunit of voltage-gated Ca2+ channels. Febs Letters 1995;364:129-133.
13. Gurnett CA, De Waard M, Campbell KP. Dual function of the voltage-dependent $\mathrm{Ca} 2+$ channel alpha 2 delta subunit in current stimulation and subunit interaction. Neuron 1996;16:431-440.

14. Wiser O, Trus M, Tobi D, Halevi S, Giladi E, Atlas D. The alpha 2/delta subunit of voltage sensitive $\mathrm{Ca} 2+$ channels is a single transmembrane extracellular protein which is involved in regulated secretion. Febs Letters 1996;379:15-20.

15. Mikami A, Imoto K, Tanabe T, et al. Primary structure and functional expression of the cardiac dihydropyridine-sensitive calcium channel. Nature 1989;340:230-233.

16. Mori Y, Friedrich T, Kim MS, et al. Primary structure and functional expression from complementary DNA of a brain calcium channel. Nature 1991;350:398-402.

17. Hullin R, Singer-Lahat D, Freichel M, et al. Calcium channel beta subunit heterogeneity: functional expression of cloned cDNA from heart, aorta and brain. Embo J 1992;11:885-890.

18. Williams ME, Feldman DH, McCue AF, et al. Structure and functional expression of alpha 1, alpha 2, and beta subunits of a novel human neuronal calcium channel subtype. Neuron 1992;8: 71-84.

19. Brust PF, Simerson S, McCue AF, et al. Human neuronal voltagedependent calcium channels: studies on subunit structure and role in channel assembly. Neuropharmacology 1993;32:1089-1102.

20. Kang MG, Felix R, Campbell KP. Long-term regulation of voltage-gated $\mathrm{Ca}(2+)$ channels by gabapentin. FEBS Lett 2002;528: $177-182$.

21. Gurnett CA, Felix R, Campbell KP. Extracellular interaction of the voltage-dependent $\mathrm{Ca} 2+$ channel alpha2delta and alpha1 subunits. J Biol Chem 1997;272:18508-18512.

22. Wolf M, Eberhart A, Glossmann H, Striessnig J, Grigorieff N. Visualization of the domain structure of an L-type $\mathrm{Ca} 2+$ channel using electron cryo-microscopy. J Mol Biol 2003;332:171-182.

23. Bauer CS, Simerson S, McCue AF, et al. The increased trafficking of the calcium channel subunit alpha2delta-1 to presynaptic terminals in neuropathic pain is inhibited by the alpha2delta ligand pregabalin. J Neurosci 2009;29:4076-4088.

24. Hendrich J, Van Minh AT, Heblich F, et al. Pharmacological disruption of calcium channel trafficking by the alpha2delta ligand gabapentin. Proc Natl Acad Sci U S A 2008;105:36283633.

25. Takahashi M, Seagar MJ, Jones JF, Reber BF, Catterall WA Subunit structure of dihydropyridine-sensitive calcium channels from skeletal muscle. Proc Natl Acad Sci U S A 1987;84:54785482.

26. Catterall WA. Structure and function of voltage-sensitive ion channels. Science 1988;242:50-61.

27. Catterall WA. Functional subunit structure of voltage-gated calcium channels. Science 1991;253:1499-1500.

28. Black JL 3rd, Lennon VA. Identification and cloning of putative human neuronal voltage-gated calcium channel gamma-2 and gamma-3 subunits: neurologic implications. Mayo Clin Proc 1999;74:357-361

29. Kang MG, Chen CC, Felix R, et al. Biochemical and biophysical evidence for gamma 2 subunit association with neuronal voltageactivated Ca2+ channels. J Biol Chem 2001;276:32917-32924.

30. Klugbauer N, Dai S, Specht V, et al. A family of gamma-like calcium channel subunits. FEBS Lett 2000;470:189-197.

31. Letts VA, Felix R, Biddlecome GH, et al. The mouse stargazer gene encodes a neuronal $\mathrm{Ca} 2+$-channel gamma subunit. Nat Genet 1998;19:340-347.

32. Moss FJ, Viard P, Davies A, et al. The novel product of a five-exon stargazin-related gene abolishes $\mathrm{Ca}(\mathrm{V}) 2.2$ calcium channel expression. Embo J 2002;21:1514-1523.

33. Ertel EA, Campbell KP, Harpold MM, et al. Nomenclature of voltage-gated calcium channels. Neuron 2000;25:533-535.

34. Jan LY, Jan YN. Voltage-sensitive ion channels. Cell 1989;56: $13-25$.

35. Spedding M, Lepagnol J. Pharmacology of sodium and calcium channel modulation in neurons: implications for neuroprotection. Biochem Soc Trans 1995;23:633-636.

36. Tsien RW, Ellinor PT, Horne WA. Molecular diversity of voltage-dependent Ca2+ channels. Trends Pharmacol Sci 1991;12: 349-354. 
37. Finkbeiner S, Greenberg ME. Ca2 + channel-regulated neuronal gene expression. J Neurobiol 1998;37:171-189.

38. Belardetti F, Zamponi GW. Linking calcium-channel isoforms to potential therapies. Curr Opin Investig Drugs 2008;9:707-715.

39. Davies JN, Zamponi GW. Old proteins, developing roles: the regulation of calcium channels by synaptic proteins. Channels (Austin) 2008;2:130-138.

40. Zamponi GW, Lewis RJ, Todorovic SM, Arneric SP, Snutch TP. Role of voltage-gated calcium channels in ascending pain pathways. Brain Res Rev 2009;60:84-89.

41. Catterall WA, Dib-Hajj S, Meisler MH, Pietrobon D. Inherited neuronal ion channelopathies: new windows on complex neurological diseases. J Neurosci 2008;28:11768-11777.

42. Yaksh TL. Calcium channels as therapeutic targets in neuropathic pain. J Pain 2006;7:S13-30.

43. McGivern JG, McDonough SI. Voltage-gated calcium channels as targets for the treatment of chronic pain. Curr Drug Targets CNS Neurol Disord 2004;3:457-478.

44. Bourinet E, Zamponi GW. Voltage gated calcium channels as targets for analgesics. Curr Top Med Chem 2005;5:539-546.

45. Schroeder CI, Doering CJ, Zamponi GW, Lewis RJ. N-type calcium channel blockers: novel therapeutics for the treatment of pain. Med Chem 2006;2:535-543.

46. Kisilevsky AE, Zamponi GW. Presynaptic calcium channels: structure, regulators, and blockers. Handb Exp Pharmacol 2008: $45-75$.

47. Catterall WA, Few AP. Calcium channel regulation and presynaptic plasticity. Neuron 2008;59:882-901.

48. Fuchs A, Rigaud M, Sarantopoulos CD, Filip P, Hogan QH. Contribution of calcium channel subtypes to the intracellular calcium signal in sensory neurons: the effect of injury. Anesthesiology 2007; 107:117-127.

49. Diaz A, Dickenson AH. Blockade of spinal N- and P-type, but not L-type, calcium channels inhibits the excitability of rat dorsal horn neurones produced by subcutaneous formalin inflammation. Pain 1997;69:93-100.

50. Matthews EA, Dickenson AH. Effects of spinally delivered Nand P-type voltage-dependent calcium channel antagonists on dorsal horn neuronal responses in a rat model of neuropathy. Pain 2001;92:235-246.

51. Matthews EA, Dickenson AH. Effects of ethosuximide, a T-type $\mathrm{Ca}(2+)$ channel blocker, on dorsal horn neuronal responses in rats. Eur J Pharmacol 2001;415:141-149.

52. Vanegas H, Schaible H. Effects of antagonists to high-threshold calcium channels upon spinal mechanisms of pain, hyperalgesia and allodynia. Pain 2000;85:9-18.

53. Westenbroek RE, Hell JW, Warner C, Dubel SJ, Snutch TP, Catterall WA. Biochemical properties and subcellular distribution of an N-type calcium channel alpha 1 subunit. Neuron 1992;9: $1099-1115$

54. Kerr LM, Filloux F, Olivera BM, Jackson H, Wamsley JK. Autoradiographic localization of calcium channels with [125I]omega-conotoxin in rat brain. Eur J Pharmacol 1988;146:181-183.

55. Gohil K, Bell JR, Ramachandran J, Miljanich GP. Neuroanatomical distribution of receptors for a novel voltage-sensitive calciumchannel antagonist, SNX-230 (omega-conopeptide MVIIC). Brain Res 1994;653:258-266.

56. Pertovaara A. Noradrenergic pain modulation. Prog Neurobiol 2006;80:53-83.

57. Bourinet E, Soong TW, Stea A, Snutch TP. Determinants of the $\mathrm{G}$ protein-dependent opioid modulation of neuronal calcium channels. Proc Natl Acad Sci U S A 1996;93:1486-1491.

58. Altier C, Zamponi GW. Targeting $\mathrm{Ca} 2+$ channels to treat pain: T-type versus N-type. Trends Pharmacol Sci 2004;25:465-470.

59. Chaplan SR, Pogrel JW, Yaksh TL. Role of voltage-dependent calcium channel subtypes in experimental tactile allodynia. J Pharmacol Exp Ther 1994;269:1117-1123.

60. Maggi CA, Tramontana M, Cecconi R, Santicioli P. Neurochemical evidence for the involvement of $\mathrm{N}$-type calcium channels in transmitter secretion from peripheral endings of sensory nerves in guinea pigs. Neurosci Lett 1990;114:203-206.

61. Santicioli P, Del Bianco E, Tramontana M, Geppetti P, Maggi CA. Release of calcitonin gene-related peptide like-immunoreac- tivity induced by electrical field stimulation from rat spinal afferents is mediated by conotoxin-sensitive calcium channels. Neurosci Lett 1992;136:161-164.

62. Evans AR, Nicol GD, Vasko MR. Differential regulation of evoked peptide release by voltage-sensitive calcium channels in rat sensory neurons. Brain Res 1996;712:265-273.

63. Saegusa H, Kurihara T, Zong S, et al. Suppression of inflammatory and neuropathic pain symptoms in mice lacking the N-type Ca2 + channel. Embo J 2001;20:2349-2356.

64. Saegusa H, Matsuda Y, Tanabe T. Effects of ablation of N- and R-type $\mathrm{Ca}(2+)$ channels on pain transmission. Neurosci Res 2002;43:1-7.

65. Hatakeyama S, Wakamori M, Ino M, et al. Differential nociceptive responses in mice lacking the alpha(1B) subunit of N-type $\mathrm{Ca}(2+)$ channels. Neuroreport 2001;12:2423-2427.

66. Bell TJ, Thaler C, Castiglioni AJ, Helton TD, Lipscombe D. Cell-specific alternative splicing increases calcium channel current density in the pain pathway. Neuron 2004;41:127-138.

67. Lin Y, McDonough SI, Lipscombe D. Alternative Splicing in the voltage-sensing region of N-type CaV2.2 channels modulates channel kinetics. J Neurophysiol 2004;92:2820-2830.

68. Lin Z, Haus S, Edgerton J, Lipscombe D. Identification of functionally distinct isoforms of the $\mathrm{N}$-type $\mathrm{Ca} 2+$ channel in rat sympathetic ganglia and brain. Neuron 1997;18:153-166.

69. Miljanich GP. In: Venoms to drugs. Heron Island, Australia. 2005. Available at: http://www.venomstodrugs.com/index.html? page $=107301 \&$ pid $=0$.

70. Hillyard DR, Monje VD, Mintz IM, et al. A new Conus peptide ligand for mammalian presynaptic $\mathrm{Ca} 2+$ channels. Neuron 1992; 9:69-77.

71. Lewis RJ, Nielsen KJ, Craik DJ, et al. Novel omega-conotoxins from Conus catus discriminate among neuronal calcium channel subtypes. J Biol Chem 2000;275:35335-35344.

72. Nadasdi L, Yamashiro D, Chung D, Tarczy-Hornoch K, Adriaenssens P, Ramachandran J. Structure-activity analysis of a Conus peptide blocker of N-type neuronal calcium channels. Biochemistry 1995;34:8076-8081.

73. Smith MT, Cabot PJ, Ross FB, Robertson AD, Lewis RJ. The novel N-type calcium channel blocker, AM336, produces potent dose-dependent antinociception after intrathecal dosing in rats and inhibits substance $\mathrm{P}$ release in rat spinal cord slices. Pain 2002;96:119-127.

74. Wang YX, Gao D, Pettus M, Phillips C, Bowersox SS. Interactions of intrathecally administered ziconotide, a selective blocker of neuronal N-type voltage-sensitive calcium channels, with morphine on nociception in rats. Pain 2000;84:271-281.

75. Wang YX, Pettus M, Gao D, Phillips C, Scott Bowersox S. Effects of intrathecal administration of ziconotide, a selective neuronal $\mathrm{N}$-type calcium channel blocker, on mechanical allodynia and heat hyperalgesia in a rat model of postoperative pain. Pain 2000;84:151-158.

76. Sluka KA. Blockade of N- and P/Q-type calcium channels reduces the secondary heat hyperalgesia induced by acute inflammation. J Pharmacol Exp Ther 1998;287:232-237.

77. Lynch SS, Cheng CM, Yee JL. Intrathecal ziconotide for refractory chronic pain. Ann Pharmacother 2006;40:1293-1300.

78. Klotz U. Ziconotide-a novel neuron-specific calcium channel blocker for the intrathecal treatment of severe chronic pain-a short review. Int J Clin Pharmacol Ther 2006;44:478-483.

79. Wermeling DP. Ziconotide, an intrathecally administered N-type calcium channel antagonist for the treatment of chronic pain. Pharmacotherapy 2005;25:1084-1094.

80. Atanassoff PG, Hartmannsgruber MW, Thrasher J, et al. Ziconotide, a new N-type calcium channel blocker, administered intrathecally for acute postoperative pain. Reg Anesth Pain Med 2000;25:274-278.

81. Mathur VS. Ziconotide: a new pharmacological class of drug for the management of pain. Sem Anesth Periop Med Pain 2000; 19:67-75.

82. Staats PS, Yearwood T, Charapata SG, et al. Intrathecal ziconotide in the treatment of refractory pain in patients with cancer or AIDS: a randomized controlled trial. JAMA 2004;291:63-70. 
83. Wallace MS, Charapata SG, Fisher R, et al. Intrathecal Ziconotide in the treatment of chronic non-malignant pain: a randomized, double-blind, placebo-controlled clinical trial. Neuromodulation 2006;9:75-86.

84. Lyseng-Williamson KA, Perry C. Ziconotide. CNS Drugs 2006; 20:331-341.

85. Rauck RL, Wallace MS, Leong MS, et al. A randomized, doubleblind, placebo-controlled study of intrathecal ziconotide in adults with severe chronic pain. J Pain Symptom Manage 2006;31:393406.

86. Fisher R, Hassenbusch S, Krames E, et al. A consensus statement regarding the present suggested titration for prialt (ziconotide). Neuromodulation 2005;8:153-154.

87. Saulino M. Successful reduction of neuropathic pain associated with spinal cord injury via of a combination of intrathecal hydromorphone and ziconotide: a case report. Spinal Cord 2007;45: $749-752$.

88. Staats PS, Yearwood T, Charapata SG, et al. Intrathecal ziconotide in the treatment of refractory pain in patients with cancer or AIDS: a randomized controlled trial. JAMA 2004;291:63-70.

89. Snutch TP. Targeting chronic and neuropathic pain: the N-type calcium channel comes of age. NeuroRx 2005;2:662-670.

90. Wermeling DP, Berger JR. Ziconotide infusion for severe chronic pain: case series of patients with neuropathic pain. Pharmacotherapy 2006;26:395-402.

91. Yarotskyy V, Elmslie KS. Omega-conotoxin GVIA alters gating charge movement of N-type (CaV2.2) calcium channels. J Neurophysiol 2009;101:332-340.

92. Thompson JC, Dunbar E, Laye RR. Treatment challenges and complications with ziconotide monotherapy in established pump patients. Pain Physician 2006;9:147-152.

93. Vitale V, Battelli D, Gasperoni E, Monachese N. Intrathecal therapy with ziconotide: clinical experience and considerations on its use. Minerva Anestesiol 2008;74:727-733.

94. Deer T, Krames ES, Hassenbusch SJ, et al. Polyanalgesic Consensus Conference 2007: recommendations for the management of pain by intrathecal (intraspinal) drug delivery: report of an interdisciplinary expert panel. Neuromodulation 2007;10:300328.

95. Smith HS, Deer TR, Staats PS, Singh V, Sehgal N, Cordner H. Intrathecal drug delivery. Pain Physician 2008;11:S89-S104.

96. Pin JP, Bockaert J. Omega-conotoxin GVIA and dihydropyridines discriminate two types of $\mathrm{Ca} 2+$ channels involved in GABA release from striatal neurons in culture. Eur J Pharmacol 1990;188:81-84.

97. Zhang SP, Kauffman J, Yagel SK, Codd EE. High-throughput screening for N-type calcium channel blockers using a scintillation proximity assay. J Biomol Screen 2006;11:672-677.

98. Scott DA, Wright CE, Angus JA. Actions of intrathecal omegaconotoxins CVID, GVIA, MVIIA, and morphine in acute and neuropathic pain in the rat. Eur J Pharmacol 2002;451:279-286.

99. Malmberg AB, Yaksh TL. Effect of continuous intrathecal infusion of omega-conopeptides, N-type calcium-channel blockers, on behavior and antinociception in the formalin and hot-plate tests in rats. Pain 1995;60:83-90.

100. Cousins M, Goucke R, Cher L, Brooker C. A phase I clinical trial of AM336, a novel N-type calcium channel blocker. IASP Press: 10th World Congress on Pain 2002;200:615-P249.

101. Knutsen LJ, Hobbs CJ, Earnshaw CG, et al. Synthesis and SAR of novel 2-arylthiazolidinones as selective analgesic N-type calcium channel blockers. Bioorg Med Chem Lett 2007;17:662667.

102. Herlitze S, Garcia DE, Mackie K, Hille B, Scheuer T, Catterall WA. Modulation of $\mathrm{Ca} 2+$ channels by G-protein beta gamma subunits. Nature 1996;380:258-262.

103. Pirec V, Laurito CE, Lu Y, Yeomans DC. The combined effects of N-type calcium channel blockers and morphine on A delta versus C fiber mediated nociception. Anesth Analg 2001;92: 239-243.

104. Martin TJ, Eisenach JC. Pharmacology of opioid and nonopioid analgesics in chronic pain states. J Pharmacol Exp Ther 2001; 299:811-817.
105. Sharpe IA, Gehrmann J, Loughnan ML, et al. Two new classes of conopeptides inhibit the alpha1-adrenoceptor and noradrenaline transporter. Nat Neurosci 2001;4:902-907.

106. Paczkowski FA, Sharpe IA, Dutertre S, Lewis RJ. chi-Conotoxin and tricyclic antidepressant interactions at the norepinephrine transporter define a new transporter model. J Biol Chem 2007; 282:17837-17844.

107. Nelson MT, Joksovic PM, Perez-Reyes E, Todorovic SM. The endogenous redox agent L-cysteine induces T-type $\mathrm{Ca} 2+$ channel-dependent sensitization of a novel subpopulation of rat peripheral nociceptors. J Neurosci 2005;25:8766-8775.

108. Todorovic SM, Jevtovic-Todorovic V. The role of T-type calcium channels in peripheral and central pain processing. CNS Neurol Disord Drug Targets 2006;5:639-653.

109. Sekizawa SI, French AS, Torkkeli PH. Low-voltage-activated calcium current does not regulate the firing behavior in paired mechanosensory neurons with different adaptation properties. J Neurophysiol 2000;83:746-753.

110. Jagodic MM, Pathirathna S, Nelson MT, et al. Cell-specific alterations of T-type calcium current in painful diabetic neuropathy enhance excitability of sensory neurons. J Neurosci 2007;27: $3305-3316$

111. Jagodic MM, Pathirathna S, Joksovic PM, et al. Upregulation of the T-type calcium current in small rat sensory neurons after chronic constrictive injury of the sciatic nerve. J Neurophysiol 2008;99:3151-3156.

112. Dogrul A, Gardell LR, Ossipov MH, Tulunay FC, Lai J, Porreca F. Reversal of experimental neuropathic pain by T-type calcium channel blockers. Pain 2003;105:159-168.

113. Flatters SJ, Bennett GJ. Ethosuximide reverses paclitaxel- and vincristine-induced painful peripheral neuropathy. Pain 2004;109: $150-161$.

114. Todorovic SM, Meyenburg A, Jevtovic-Todorovic V. Redox modulation of peripheral T-type $\mathrm{Ca} 2+$ channels in vivo: alteration of nerve injury-induced thermal hyperalgesia. Pain 2004; 109:328-339.

115. Todorovic SM, Meyenburg A, Jevtovic-Todorovic V. Mechanical and thermal antinociception in rats following systemic administration of mibefradil, a T-type calcium channel blocker. Brain Res 2002;951:336-340.

116. Choi S, Na HS, Kim J, et al. Attenuated pain responses in mice lacking $\mathrm{Ca}(\mathrm{V}) 3.2$ T-type channels. Genes Brain Behav 2007;6: 425-431.

117. Bourinet E, Alloui A, Monteil A, et al. Silencing of the Cav3.2 T-type calcium channel gene in sensory neurons demonstrates its major role in nociception. Embo J 2005;24:315-324.

118. Shin HS, Cheong EJ, Choi S, Lee J, Na HS. T-type Ca2+ channels as therapeutic targets in the nervous system. Curr Opin Pharmacol 2008;8:33-41.

119. Todorovic SM, Jevtovic-Todorovic V, Meyenburg A, et al. Redox modulation of T-type calcium channels in rat peripheral nociceptors. Neuron 2001;31:75-85.

120. Todorovic SM, Jevtovic-Todorovic V. Regulation of T-type calcium channels in the peripheral pain pathway. Channels (Austin) 2007;1:238-245.

121. Dworkin RH, O'Connor AB, Backonja M, et al. Pharmacologic management of neuropathic pain: evidence-based recommendations. Pain 2007;132:237-251.

122. Raskin P, Donofrio PD, Rosenthal NR, et al. Topiramate vs placebo in painful diabetic neuropathy: analgesic and metabolic effects. Neurology 2004;63:865-873.

123. Thienel U, Neto W, Schwabe SK, Vijapurkar U. Topiramate in painful diabetic polyneuropathy: findings from three double-blind placebo-controlled trials. Acta Neurol Scand 2004;110:221-231.

124. Khoromi S, Patsalides A, Parada S, Salehi V, Meegan JM, Max MB. Topiramate in chronic lumbar radicular pain. J Pain 2005; 6:829-836.

125. Fowler JA, Shen JY, Bettinger TL. Successful use of topiramate in a patient with severe postherpetic neuralgia. Ann Pharmacother 2009;43:139-142.

126. Chong MS, Libretto SE. The rationale and use of topiramate for treating neuropathic pain. Clin J Pain 2003;19:59-68. 
127. Ophoff RA, Terwindt GM, Vergouwe MN, et al. Familial hemiplegic migraine and episodic ataxia type- 2 are caused by mutations in the Ca2+ channel gene CACNL1A4. Cell 1996;87:543552.

128. Pietrobon D, Striessnig J. Neurobiology of migraine. Nat Rev Neurosci 2003;4:386-398.

129. Pietrobon D. Familial hemiplegic migraine. Neurotherapeutics 2007:4:274-284.

130. Murakami M, Nakagawasai O, Suzuki T, et al. Antinociceptive effect of different types of calcium channel inhibitors and the distribution of various calcium channel alpha 1 subunits in the dorsal horn of spinal cord in mice. Brain Res 2004;1024:122-129.

131. Luo ZD, Chaplan SR, Higuera ES, et al. Upregulation of dorsal root ganglion (alpha)2(delta) calcium channel subunit and its correlation with allodynia in spinal nerve-injured rats. J Neurosci 2001;21:1868-1875.

132. Luo ZD, Calcutt NA, Higuera ES, et al. Injury type-specific calcium channel alpha 2 delta-1 subunit up-regulation in rat neuropathic pain models correlates with antiallodynic effects of gabapentin. J Pharmacol Exp Ther 2002;303:1199-1205.

133. Newton RA, Bingham S, Case PC, Sanger GJ, Lawson SN. Dorsal root ganglion neurons show increased expression of the calcium channel alpha2delta-1 subunit following partial sciatic nerve injury. Brain Res Mol Brain Res 2001;95:1-8.

134. Wang H, Sun H, Della Penna K, et al. Chronic neuropathic pain is accompanied by global changes in gene expression and shares pathobiology with neurodegenerative diseases. Neuroscience 2002;114:529-546.

135. Valder CR, Liu JJ, Song YH, Luo ZD. Coupling gene chip analyses and rat genetic variances in identifying potential target genes that may contribute to neuropathic allodynia development. J Neurochem 2003;87:560-573.

136. Li CY, Song YH, Higuera ES, Luo ZD. Spinal dorsal horn calcium channel alpha2delta-1 subunit upregulation contributes to peripheral nerve injury-induced tactile allodynia. J Neurosci 2004;24:8494-8499.

137. Gee NS, Brown JP, Dissanayake VU, Offord J, Thurlow R, Woodruff GN. The novel anticonvulsant drug, gabapentin (Neurontin), binds to the alpha2delta subunit of a calcium channel. J Biol Chem 1996;271:5768-5776.

138. Hwang JH, Yaksh TL. Effect of subarachnoid gabapentin on tactile-evoked allodynia in a surgically induced neuropathic pain model in the rat. Regional Anesthesia 1997;22:249-256.

139. Abdi S, Lee DH, Chung JM. The anti-allodynic effects of amitriptyline, gabapentin, and lidocaine in a rat model of neuropathic pain. Anesth Analg 1998;87:1360-1366.

140. Field MJ, McCleary S, Hughes J, Singh L. Gabapentin and pregabalin, but not morphine and amitriptyline, block both static and dynamic components of mechanical allodynia induced by streptozocin in the rat. Pain 1999;80:391-398.

141. Backonja M, Beydoun A, Edwards KR, et al. Gabapentin for the symptomatic treatment of painful neuropathy in patients with diabetes mellitus: a randomized controlled trial. JAMA 1998;280: 1831-1836.

142. Rosner H, Rubin L, Kestenbaum A. Gabapentin adjunctive therapy in neuropathic pain states. Clin J Pain 1996;12:56-58.

143. Rosenberg JM, Harrell C, Ristic H, Werner RA, de Rosayro AM. The effect of gabapentin on neuropathic pain. Clin J Pain 1997; $13: 251-255$

144. Nudler S, Piriz J, Urbano FJ, Rosato-Siri MD, Renteria ES, Uchitel OD. Ca2 + channels and synaptic transmission at the adult, neonatal, and $\mathrm{P} / \mathrm{Q}$-type deficient neuromuscular junction. Ann N Y Acad Sci 2003;998:11-17.

145. Perrier JF, Alaburda A, Hounsgaard J. Spinal plasticity mediated by postsynaptic L-type $\mathrm{Ca} 2+$ channels. Brain Res Brain Res Rev 2002;40:223-229.

146. Westenbroek RE, Hoskins L, Catterall WA. Localization of $\mathrm{Ca} 2+$ channel subtypes on rat spinal motor neurons, interneurons, and nerve terminals. J Neurosci 1998;18:6319-6330.

147. Kato A, Ohkubo T, Kitamura K. Algogen-specific pain processing in mouse spinal cord: differential involvement of voltagedependent $\mathrm{Ca}(2+)$ channels in synaptic transmission. Br J Pharmacol 2002;135:1336-1342.
148. Reid CA, Bekkers JM, Clements JD. Presynaptic Ca2 + channels: a functional patchwork. Trends Neurosci 2003;26:683-687.

149. Talley EM, Cribbs LL, Lee JH, Daud A, Perez-Reyes E, Bayliss DA. Differential distribution of three members of a gene family encoding low voltage-activated (T-type) calcium channels. J Neurosci 1999;19:1895-1911.

150. Lambert RC, McKenna F, Maulet Y, et al. Low-voltage-activated $\mathrm{Ca} 2+$ currents are generated by members of the CavT subunit family $($ alpha $1 \mathrm{G} / \mathrm{H})$ in rat primary sensory neurons. J Neurosci 1998;18:8605-8613.

151. McCallum JB, Kwok WM, Mynlieff M, Bosnjak ZJ, Hogan QH. Loss of T-type calcium current in sensory neurons of rats with neuropathic pain. Anesthesiology 2003;98:209-216.

152. Boroujerdi A, Kim HK, Lyu YS, et al. Injury discharges regulate calcium channel alpha-2-delta-1 subunit upregulation in the dorsal horn that contributes to initiation of neuropathic pain. Pain 2008.

153. Zareba G. New treatment options in the management of fibromyalgia: role of pregabalin. Neuropsychiatr Dis Treat 2008;4:11931201.

154. Stahl SM. Anticonvulsants and the relief of chronic pain: pregabalin and gabapentin as alpha(2)delta ligands at voltage-gated calcium channels. J Clin Psychiatry 2004;65:596-597.

155. Rowbotham M, Harden N, Stacey B, Bernstein P, Magnus-Miller L. Gabapentin for the treatment of postherpetic neuralgia: a randomized controlled trial. JAMA 1998;280:1837-1842.

156. Rice AS, Maton S. Gabapentin in postherpetic neuralgia: a randomised, double blind, placebo controlled study. Pain 2001;94: 215-224.

157. Anhut H, Ashman P, Feuerstein TJ, Sauermann W, Saunders M, Schmidt B. Gabapentin (Neurontin) as add-on therapy in patients with partial seizures: a double-blind, placebo-controlled study. The International Gabapentin Study Group. Epilepsia 1994;35: $795-801$

158. Garcia-Borreguero D, Larrosa O, de la Llave Y, Verger K, Masramon X, Hernandez G. Treatment of restless legs syndrome with gabapentin: a double-blind, cross-over study. Neurology 2002;59: $1573-1579$

159. Pollack MH, Matthews J, Scott EL. Gabapentin as a potential treatment for anxiety disorders. Am J Psychiatry 1998;155:992993.

160. Bockbrader H. Clinical pharmacokinetics of gabapentin. Drugs Today 1995;31:613-619.

161. McLean MJ. Clinical pharmacokinetics of gabapentin. Neurology 1994;44:S17-22; discussion S31-12.

162. Stewart BH, Kugler AR, Thompson PR, Bockbrader HN. A saturable transport mechanism in the intestinal absorption of gabapentin is the underlying cause of the lack of proportionality between increasing dose and drug levels in plasma. Pharm Res 1993;10:276-281.

163. Nicholson B. Gabapentin use in neuropathic pain syndromes. Acta Neurol Scand 2000;101:359-371.

164. Hemstreet B, Lapointe M. Evidence for the use of gabapentin in the treatment of diabetic peripheral neuropathy. Clin Ther 2001; 23:520-531.

165. Todorov AA, Kolchev CB, Todorov AB. Tiagabine and gabapentin for the management of chronic pain. Clin J Pain 2005;21: $358-361$.

166. Arnold LM, Goldenberg DL, Stanford SB, et al. Gabapentin in the treatment of fibromyalgia: a randomized, double-blind, placebo-controlled, multicenter trial. Arthritis Rheum 2007;56: 1336-1344.

167. Matthews EA, Dickenson AH. A combination of gabapentin and morphine mediates enhanced inhibitory effects on dorsal horn neuronal responses in a rat model of neuropathy. Anesthesiology 2002;96:633-640.

168. Gilron I, Bailey JM, Tu D, Holden RR, Weaver DF, Houlden RL. Morphine, gabapentin, or their combination for neuropathic pain. N Engl J Med 2005;352:1324-1334.

169. Hanna M, O'Brien C, Wilson MC. Prolonged-release oxycodone enhances the effects of existing gabapentin therapy in painful diabetic neuropathy patients. Eur J Pain 2008;12:804-813. 
170. Gu R, Gusler GM, Hou SYE, et al. Extended release and doseproportionality of a novel gabapentin formulation. The 88th Annual Meeting of the Endocrine Society; 2006:319 (abstract).

171. Gordi T, Hou E, Kasichayanula S, Berner B. Pharmacokinetics of gabapentin after a single day and at steady state following the administration of gastric-retentive- extended-release and immediate-release tablets: a randomized, open-label, multiple-dose, three-way crossover, exploratory study in healthy subjects. Clin Ther 2008;30:909-916.

172. Sabatowski R, Gálvez R, Cherry DA, et al. Pregabalin reduces pain and improves sleep and mood disturbances in patients with post-herpetic neuralgia: results of a randomised, placebo-controlled clinical trial. Pain 2004;109:26-35.

173. Irving G, Jensen M, Cramer M, et al. Efficacy and tolerability of gastric-retentive gabapentin for the treatment of postherpetic neuralgia: results of a double-blind, randomized, placebo-controlled clinical trial. Clin J Pain 2009;25:185-192.

174. Cundy KC, Sastry S, Luo W, Zou J, Moors TL, Canafax DM. Clinical pharmacokinetics of XP13512, a novel transported prodrug of gabapentin. J Clin Pharmacol 2008;48:1378-1388.

175. Kushida CA, Becker PM, Ellenbogen AL, Canafax DM, Barrett RW. Randomized, double-blind, placebo-controlled study of XP13512/GSK1838262 in patients with RLS. Neurology 2009; 72:439-446.

176. Gajraj NM. Pregabalin: its pharmacology and use in pain management. Anesth Analg 2007;105:1805-1815.

177. Dworkin RH, Kirkpatrick P. Pregabalin. Nat Rev Drug Discov 2005;4:455-456.

178. Frampton JE, Foster RH. Pregabalin: in the treatment of postherpetic neuralgia. Drugs 2005;65:111-120.

179. Gray P. Pregabalin in the management of central neuropathic pain. Expert Opin Pharmacother 2007;8:3035-3041.

180. Zareba G. Pregabalin: a new agent for the treatment of neuropathic pain. Drugs Today 2007;41:509-516.

181. Owen RT. Pregabalin: its efficacy, safety and tolerability profile in fibromyalgia syndrome. Drugs Today (Barc) 2007;43:857863.

182. Stacey BR, Swift JN. Pregabalin for neuropathic pain based on recent clinical trials. Curr Pain Headache Rep 2006;10:179-184.

183. Crofford LJ, Rowbotham MC, Mease PJ, et al. Pregabalin for the treatment of fibromyalgia syndrome: results of a randomized, double-blind, placebo-controlled trial. Arthritis Rheum 2005;52:1264-1273.

184. Calandre EP, Morillas-Arques P, Rodriguez-Lopez CM, RicoVillademoros F, Hidalgo J. Pregabalin augmentation of quetiapine therapy in the treatment of fibromyalgia: an open-label, prospective trial. Pharmacopsychiatry 2007;40:68-71.

185. Mease PJ, Russell IJ, Arnold LM, et al. A randomized, doubleblind, placebo-controlled, phase III trial of pregabalin in the treatment of patients with fibromyalgia. J Rheumatol 2008;35: 502-514.

186. Arnold LM, Russell IJ, Diri EW, et al. A 14-week, randomized, double-blinded, placebo-controlled monotherapy trial of pregabalin in patients with fibromyalgia. J Pain 2008;9:792-805.

187. Crofford LJ, Mease PJ, Simpson SL, et al. Fibromyalgia relapse evaluation and efficacy for durability of meaningful relief (FREEDOM): a 6-month, double-blind, placebo-controlled trial with pregabalin. Pain 2008;136:419-431.

188. Recla JM, Sarantopoulos CD. Combined use of pregabalin and memantine in fibromyalgia syndrome treatment: a novel analgesic and neuroprotective strategy? Med Hypotheses 2009;73:177183.

189. De Lange FP, Knoop H, Bleijenberg G, Van der Meer JW, Hagoort P, Toni I. Gray matter volume reduction in the chronic fatigue syndrome. Neuroimage 2005;26:777-781.

190. Kuchinad A, Schweinhardt P, Seminowicz DA, Wood PB, Chizh BA, Bushnell MC. Accelerated brain gray matter loss in fibromyalgia patients: premature aging of the brain? J Neurosci 2007; 27:4004-4007.

191. Okada T, Tanaka M, Kuratsune H, Watanabe Y, Sadato N. Mechanisms underlying fatigue: a voxel-based morphometric study of chronic fatigue syndrome. BMC Neurol 2004;4:14.

192. Schmidt-Wilcke T, Luerding R, Weigand T, et al. Striatal grey matter increase in patients suffering from fibromyalgia--a voxelbased morphometry study. Pain 2007;132(suppl 1):S109-116.

193. Schmidt-Wilcke T, Leinisch E, Straube A, et al. Gray matter decrease in patients with chronic tension type headache. Neurology 2005;65:1483-1486.

194. Villarreal G, Hamilton DA, Petropoulos H, et al. Reduced hippocampal volume and total white matter volume in posttraumatic stress disorder. Biol Psychiatry 2002;52:119-125. 